\title{
Nutritional Composition of Malted Barley Residue from Brewery
}

\author{
Jaqueline Andrea Custódio Trevizan ${ }^{1}$, Graciene de Souza Bido ${ }^{1}$, Ariana Ferrari ${ }^{1,2}$ \& Daniele Fernanda Felipe ${ }^{1,2}$ \\ ${ }^{1}$ Master Program in Science, Technology and Food Safety, Cesumar University - Unicesumar, Maringá-PR, \\ Brazil \\ ${ }^{2}$ Master Program in Clean Technologies, Cesumar University - Unicesumar, Researcher at ICETI - Cesumar \\ Institute of Science, Technology and Innovation. Maringá-PR, Brazil \\ Correspondence: Daniele Fernanda Felipe, Master Program in Clean Technologies, Cesumar University - \\ Unicesumar, Maringá-PR, Brazil, 87050-900. E-mail: daniele.felipe@unicesumar.edu.br
}

Received: November 25, $2020 \quad$ Accepted: December 29, 2020 Online Published: January 4, 2021

doi:10.5539/jms.v11n1p27ＵRL: https://doi.org/10.5539/jms.v11n1p27

\begin{abstract}
The reuse of residue is an alternative that benefits the industries, adding value to the residue and still reducing the costs necessary with the treatment before its disposal, but it can also enrich human food. The malted barley residue (malt bagasse) is the main residue obtained in the manufacture of beer. However, it is often discarded in the environment incorrectly or used as feed. Its nutritional potential, its ease of obtaining and its low cost, are incentives for this ingredient to be used in food. The present study is aimed at carrying out the physical-chemical characterization of the malted barley residue, in order to assess its nutritional potential. Physical-chemical analysis showed that the bran from malted barley residue presented high content of fibre, proteins and minerals, mainly phosphorus, in addition to a significant amount of potassium, iron and calcium and low sodium content. Thus, the malted barley residue showed nutritional potential to be used as ingredient in food formulation, being a sustainable way of the food industry to take advantage of this residue. The malted barley residue can be an important ingredient in the production of breads, cakes and cookies, among other preparations. These would be low-cost foods, representing savings both for the beer sector, which needs to dispose off the residue, and for the food industry, in addition to contributing to the preservation of the environment. Thus, the present study shows that the reuse of malted barley residue is a sustainable practice with environmental, economic and nutritional importance.
\end{abstract}

Keywords: beer, fibre, malt bagasse, nutritional composition, residue, reuse

\section{Introduction}

The environmental dimension of sustainability addresses the care that must be taken in productive activities so that ecosystems maintain their capacity for recomposition, even with the interference of man (Liszbinski et al., 2020). Considering the generation of waste in these productive activities, several studies have been conducted on the sources and characteristics of wastes as well as the possible adverse effect of inappropriate handling and best practices for reuse (Amasuomo \& Baird, 2016). Although the product is the purpose of the industry, processing generates waste. These represent loss of raw material, inputs, by-products or main product, requiring time and capital for its management (Veronezzi \& Jorge, 2012). Thus, several researches have studied the adoption of management models which are capable of minimizing consumption and waste, and making food supply sustainable (Colella \& Jambrenghi, 2020).

The upcycling of by-products from agro-food processes is currently one of the main circular economy principles (Nocente, Taddei, Galassi, \& Gazza, 2019). As the amount of waste generated can reach many tons, adding value to this by-product is of economic and environmental interest, with the need for scientific and technological research that enables its efficient, economic and safe use (Saraiva, Vital, Anjo, Cesaro, \& Matumoto-Pintro, 2018). This amount of waste generated by the food industry in Brazil has enormous potential, but it has increasingly worried of environmentalists of the country (do Nascimento Filho \& Franco, 2015).

The agro-industrial raw material processing industries generate a large amount of waste, formed mainly by solid residues such as husks, seeds and bagasse, which come from the processing of various crops (sugar cane, rice, grapes, barley, among others) (Saraiva et al., 2018). These residues have a high nutritional value and are composed of vitamins, minerals, fibers, antioxidant compounds and essential nutrients for health, which can be 
reused. However, they are still wasted in most industries (Araújo et al., 2018). This reality is worrying since they have great potential for a new and rich food source, and minimize waste of food (Veronezi \& Jorge, 2012).

Some of these residues are used as animal feed or disposed in the field, however, most are still discarded without treatment, causing damage to the environment due to the production of organic waste (Melo et al., 2011; Do Nascimento Filho \& Franco, 2015). This is because the waste generated needs to be treated before its disposal, which requires cost and labor, and is considered, in many cases, an operating cost for companies. When the disposal is done incorrectly, the waste can cause environmental damage, acting as a source of environmental contamination (Lousada Junior, Neiva, Rodriguez, Pimentel, \& Lôbo, 2005; Gaete, de Souza Teodoro, \& Martinazzo, 2020; Ricardino, Souza, \& da Silva Neto, 2020).

Thus, the reuse of waste is an alternative that benefits the industries, adding value to what was discarded and still reducing the costs necessary with the treatment before its disposal, but it can also enrich human food (Saraiva et al., 2018). The use of agro-industrial waste as a source of raw material for new products has aroused the interest of both researchers and the manufacturing industries. In recent years, the sustainable use of these by-products generated in the agrifood sector has become increasingly important (Nocente et al., 2019). An example is the transformation of malt bagasse into a food ingredient in the preparation of a flour with functional characteristics represents a good strategy for breweries (Costa, Silva, Louzada, \& Queiroz, 2020).

Considered the most consumed alcoholic beverage in the world, with 200 million litres per year, beer is produced with the basic ingredients: water, malt, hops and yeast (Albanese, Ciriminna, Meneguzzo, \& Pagliaro, 2017). The by-product resulting from beer production found in greater quantity is the malted barley residue, also called malt bagasse, which represents around $85 \%$ of the total generated by the beer industry. The proportion is $20 \mathrm{~kg}$ of residue for every 100 litres of beer (Aliyu \& Bala, 2011; Guo, Du, Zhang, Zhang, \& Jin, 2014). The malt bagasse is acquired from one of the initial brewing steps called mashing. "During this elevated temperature process, all soluble matter is extracted into the mash from the barley malt which, after lautering (or mash filtration), is separated into wort (liquid) and spent grain (solid) components" (Waters, Jacob, Titze, \& Arendt, 2012).

This residue has been discarded in nature causing damage to the environment, or used as animal feed due to its nutritional benefits and relatively low cost (Stefanello et al., 2014; Trujillo et al., 2018). Due to the significant amount that is produced annually, this agro-industrial by-product derived from breweries must be valued (Mussatto, 2014). In addition to supplying the demand for malt bagasse for use as animal feed, encouraging the processing of this residue may favor the elimination of the environmental risk that the residues may cause to the environment, if they are eliminated in nature, and at the same time generate wealth, employment and local development (Borges \& de Assis, 2010).

Malt bagasse is produced by both small and large breweries, with great availability and low cost. It is generally intended for animal feed, but there are studies for use also in the manufacture of ethanol, lactic acid, activated carbon, xylitol, thermochemical conversion and complement in human food, as well as raw material for the production of paper and some chemical products (Aliyu \& Bala, 2011; Budaraju, Mallikarjunan, Annor, Schoenfuss, \& Raun, 2018; Mussatto, 2014).

Research on the centesimal composition of the malt bagasse indicates that there is a high content of fibre, ash and carbohydrates, in addition to a low content of lipids (Melo, Manfio, \& Rosa, 2016). Regarding protein, according to a study by Ktenioudaki, Chaurin, Reis and Gallagher (2012), in the preparation of a bakery product, a significant increase in the protein content was found in recipes that used malt bagasse. The partial or total replacement of wheat flour by malt bagasse flour is a viable alternative, due to its nutritional value. In bakery, industries are interested in this ingredient, aiming mainly at environmental, economic and nutritional importance (Panzarini et al., 2014).

The present work proves to be important because it will make it possible to increase knowledge about the residue resulting from the brewing industry, mainly related to the nutritional composition and reduce the disposal of this residue in the environment. Thus, the objective of the present study was to carry out the physical-chemical characterization of the malted barley residue, in order to assess its nutritional potential for use as an ingredient in food, finding a sustainable way to reuse this residue.

\section{Methods}

\subsection{Malt Bagasse Processing}

To carry out the research, the malt bagasse, which was obtained from the production of a Pilsen-type beer, was purchased at a specific craft brewery, located in the city of Maringá-PR-Brazil. The residue was sent to the laboratory of the university, where the malt bagasse was weighed and then dried. The drying process was carried 
out in a forced ventilation oven at $70^{\circ} \mathrm{C}$ for 38 hours, at the same temperature and time used by Rigo, Bezerra, Rodrigues and Teixeira (2017). After drying, the residue was passed through $2 \mathrm{~mm}$ sieve and then, packed in hermetically sealed containers, being called malt bagasse bran, which was subjected to physical-chemical analysis.

\subsection{Chemical Composition of Malt Bagasse Bran}

The moisture content was determined by the gravimetric method, based on the weight loss of the material submitted to heating in an oven at $105^{\circ} \mathrm{C}$ until constant weight. The ash content (fixed mineral residue) was determined by incinerating the material in muffle at $550^{\circ} \mathrm{C}$ until constant weight. The determination of mineral elements (zinc, sodium, iron, phosphorus, manganese, calcium and potassium) was performed using atomic emission spectrometry (spectrophotometer $\operatorname{Varian}^{\circledR}$ ) with argon plasma inductively coupled with optical detection (ICP-OES), using the specific instrumental parameters for each mineral (Instituto Adolfo Lutz, 2008). To determine minerals in the sample by this method, it is necessary to make the analytes available in solution by means of prior mineralization of the sample, and subsequent dissolution of the residues with mineral acids.

The protein content of the malt bagasse was calculated by determining the percentage of total nitrogen in the sample, according to the Kjeldahl method, considering 5.75 as a conversion factor for the calculation of crude protein. The Kjeldahl method is based on three stages: digestion, distillation and titration of the sample. The amount of nitrogen present in the sample is determined by titrating the excess of the acid used in the distillation with sodium hydroxide. The total fat content was determined by the Soxhlet method, using the Soxhlet extractor $\left(\mathrm{Tecnal}^{\circledR}\right.$ ) and petroleum ether as organic solvent to extract the lipids present in the sample, followed by removal of the solvent by evaporation (Instituto Adolfo Lutz, 2008).

The amount of dietary fibre was determined by the enzymatic-gravimetric method (Instituto Adolfo Lutz, 2008). The amount of carbohydrate was calculated by difference, subtracting from 100 the contents in percentage of humidity, ashes, total fats, protein and total dietary fibre. The energy value was calculated by adding the percentages of protein and carbohydrates multiplied by factor $4(\mathrm{Kcal} / \mathrm{g})$ plus the total fat content multiplied by factor 9 (Kcal/g) (Brasil, 2003).

\subsection{Statistical Analysis}

All of the experiments were performed in triplicate, and mean values and standard deviations were calculated using GraphPad Prism v. 5.0 software (GraphPad, San Diego, CA, USA).

\section{Results and Discussion}

The results obtained in the physico-chemical characterization of the malt bagasse bran, showing the chemical composition and the energy value, are shown in Table 1.

Table 1. Chemical composition and energy value of malt bagasse bran

\begin{tabular}{ll}
\hline Chemical composition & Values (\%) \\
\hline Moisture & $4.41 \pm 0.10^{*}$ \\
Ash & $2.74 \pm 0.04^{*}$ \\
Fat & $7.69 \pm 0.08^{*}$ \\
Protein & $17.98 \pm 0.29^{*}$ \\
Fibre & $40.34 \pm 0.02^{*}$ \\
Carbohydrate & $26.84 \pm 0.35^{*}$ \\
Energy value $(\mathrm{kcal})$ & 248 \\
\hline
\end{tabular}

Note. ${ }^{*}$ Mean \pm standard deviation $(\mathrm{n}=3)$.

The malt bagasse bran had a moisture content of $4.41 \%$, being in compliance with Resolution RDC $\mathrm{n}^{\circ} 263$ of September 22, 2005 (Brasil, 2005), in which, although there is no humidity limit established for malt bagasse bran, flours in general, from other sources, such as wheat flour and wholegrain flour, have maximum moisture limits of $15 \%$. In the work developed by Ktenioudaki et al. (2012), the moisture content of the malt bagasse was $5.6 \%$, which is a value close to that found in the present study. According to Silva, Andrade, Silva and Gomes (2019), humidity must be analyzed, as it is one of the factors for the proliferation of microorganisms in the product.

Regarding the ash content, the malt bagasse bran showed a value of $2.74 \%$ (Table 1), lower than that found by Mussatto, Dragone and Roberto (2006) and Makowska, Mildner-Szkudlarz and Obuchowski (2013), which observed $4.6 \%$ and $3.76 \%$, respectively. The ashes according to Rocha, Abreu, Sousa and Corrêa (2012) 
correspond to the mineral salts present in the sample, important elements for the functioning of the organism, which are indispensable for the maintenance of health and development of the organism.

Thus, in relation to the mineral composition (Table 2), malt, zinc, sodium, iron, phosphorus, manganese, calcium and potassium bran were found in the bran, highlighting phosphorus as the mineral that was in greater concentration. The malt bagasse bran also showed a significant amount of potassium, iron and calcium. Mussatto (2014), also reported that the malt bagasse contains a variety of minerals, highlighting that phosphorus and calcium are those that are in greater quantity.

In the present study, the levels of phosphorus and calcium found were $329 \mathrm{mg} / 100 \mathrm{~g}$ and $87.5 \mathrm{mg} / 100 \mathrm{~g}$, lower than the values reported by Meneses, Martins, Teixeira and Mussatto (2013), which was $600 \mathrm{mg} / 100 \mathrm{~g}$ and 360 $\mathrm{mg} / 100 \mathrm{~g}$, respectively. However, concentrations potassium and iron levels were higher in the present study, being $90.9 \mathrm{mg} / 100 \mathrm{~g}$ and $19.5 \mathrm{mg} / 100 \mathrm{~g}$, respectively, while Meneses et al. (2013), found the values of 60 $\mathrm{mg} / 100 \mathrm{~g}$ and $15.4 \mathrm{mg} / 100 \mathrm{~g}$, respectively.

According to Resolution RDC $\mathrm{n}^{0} 360$ of December 23, 2003 (Brasil, 2003), the recommended daily intake values for the minerals phosphorus, iron, zinc and manganese are $700 \mathrm{mg}, 14 \mathrm{mg}, 7 \mathrm{mg}$ and $2.3 \mathrm{mg}$, respectively. Thus, the malt bagasse bran can be considered rich in these minerals, since it provides more than $30 \%$ of the recommended value of these nutrients in 100g of solid food (Brasil, 2012). In the case of phosphorus, the malt bagasse bran provides $47 \%$ of the recommended value, which is important because according to Santos Rolim et al. (2020), phosphorus is an essential mineral and has an important role in several functions that regulate the human body, presenting functions such as participation in the formation of teeth and bones, and also acting in chemical reactions. Regarding the minerals iron, zinc and manganese, the malt bagasse bran has an amount higher than the recommended daily intake values.

Considering the minerals calcium and potassium, the bran of the malt bagasse presents low values of these, since it provides a value less than $15 \%$ of the recommended daily intake $(8.75 \%$ and $2.60 \%$, respectively). The recommended values for these minerals are $1000 \mathrm{mg} / 100 \mathrm{~g}$ for calcium (Brasil, 2003), and $3500 \mathrm{mg} /$ day for potassium (WHO, 2006).

Regarding the amount of sodium, the malt bagasse bran presents $8.24 \mathrm{mg} / 100 \mathrm{~g}$, having very low content, which is the classification when it presents a maximum value of $40 \mathrm{mg} / 100 \mathrm{~g}$, according to Resolution $\mathrm{RDC} \mathrm{n}^{\circ} 54$ of November 12, 2012 (Brasil, 2012). This is beneficial for health since sodium consumption is one of the main factors related to the incidence of some diseases such as arterial hypertension (Nascimento, Gavron, Bowles, Chaves, \& Bortolozo, 2017). The maximum limit recommended by the World Health Organization (WHO) is $2000 \mathrm{mg} /$ day (WHO, 2006).

Table 2. Minerals composition in the malt bagasse bran

\begin{tabular}{ll}
\hline Minerals & Values $(\mathrm{mg} / 100 \mathrm{~g})$ \\
\hline Zinc & 8.80 \\
Sodium & 8.24 \\
Iron & 19.50 \\
Phosphorus & 329.0 \\
Manganese & 2.78 \\
Calcium & 87.50 \\
Potassium & 90.90 \\
\hline
\end{tabular}

Regarding total fats, the malt bagasse bran had a content of 7.69\%. Studies described by Rigo et al. (2017) and by Costa et al. (2020), found lower values such as $5.9 \%$ and $6.30 \%$, respectively. According to Resolution RDC $\mathrm{n}^{\circ}$. 54 (Brasil, 2012), it considers the total fat content low when it is at most $3 \mathrm{~g} / 100 \mathrm{~g}$, which is a lower value than that found in this study. In research by Waters et al. (2012), most of the fat content of the malt bagasse, which was reported as $7.12 \%$, corresponds to essential fatty acids (3.6\%).

The protein content present in the malt bagasse bran was $17.98 \%$, which is higher than the values found by Costa et al. (2020), Jacometti et al. (2015), and Rigo et al. (2017), which were $14.44 \%, 13.60 \%$ and $12.5 \%$, respectively. According to RDC Resolution $\mathrm{n}^{\circ} .54$ (Brasil, 2012), it can be considered that the malt bagasse bran has a high protein content, as it was found to be higher than $12 \mathrm{~g}$ of protein $/ 100 \mathrm{~g}$. According to Waters et al. (2012), the essential amino acids present in the malt bagasse represent approximately $30 \%$ of the total protein content, with lysine being the most abundant. The rest are non-essential amino acids, including mainly histidine 
and glutamic acid.

As for the dietary fibre content, the malt bagasse bran presented a value of $40.34 \%$, being considered as raw material with a high fibre content, since it would have to present a minimum of $6 \mathrm{~g} / 100 \mathrm{~g}(6 \%)$ (Brasil, 2012) to have this classification. The content found was higher than the value reported by Rigo et al. (2017), which was $29.1 \%$, but was less than the value of $48.2 \%$, reported by Waters et al. (2012). Thus, the content found demonstrates that the malt bagasse bran has a high nutritional value, since the fibre content represents almost half of its proximate composition, corresponding to $48 \%$ of the recommended daily value. Mussatto (2014) reports that the fibre present in the malt bagasse are mainly cellulose, hemicellulose and lignin.

Considering the carbohydrate content, the malt bagasse bran presented a value of $26.84 \%$, being higher than the results found by Jacometti et al. (2015), and lower than that found by Rigo et al. (2017), which were 10\%, and $45.4 \%$, respectively, discounting the fibre content in the carbohydrate content. Resolution RDC ${ }^{\circ} 54$ (Brasil, 2012), considers the carbohydrate content low when it is at most $5 \mathrm{~g} / 100 \mathrm{~g}$, which is a lower value than that found in the malt bagasse bran.

The malt bagasse bran has an energy value of $248 \mathrm{Kcal}$ per $100 \mathrm{~g}$, being considered a high value, as Resolution $\mathrm{RDC} \mathrm{n}^{\mathrm{O}} 54$ (Brasil, 2012), considers low energy value when it presents a maximum of $40 \mathrm{Kcal}$ per 100g. The high levels of carbohydrates, proteins and lipids found in the present study, contributed to the high energy value of the malt bagasse. According to Terra, Antunes, Bueno and Prado (2010), cereals largely contribute to the caloric intake of the general population, as they are consumed worldwide, by all age groups, in addition to being frequently used as raw material for the food industry.

There is a wide variation in the nutrient content in the malt bagasse due to several factors such as: variety of the barley, time of harvest, type of cereal that will be malted, in addition to the different processes used in the brewery and the quality and type of adjuncts used during the process (Aliyu \& Bala, 2011; Cordeiro, El-Aouar, \& Gusmão, 2012; Rigo et al., 2017). This can justify the differences found in the values of the chemical composition of the malt bagasse bran in the present study in relation to the values reported in the literature.

According to the Brazilian Food Composition Table - TACO (2011), wheat flour has ash contents $0.8 \%$, lipids $1.4 \%$, proteins $9.8 \%$ and fibre $2.3 \%$, lower than the values found for the malt bagasse bran in the present study. In addition, the fibre content of whole wheat flour is also lower, at $15.5 \%$. This suggests that the malt bagasse bran presents nutritional advantages, in relation to wheat flour, for the elaboration of products for human consumption.

In view of the values found, the malted barley residue, also called malt bagasse, has considerable nutritional quality, being a raw material of interest to the food industry, and may even partially or totally replace the traditional flours used. With methods that preserve nutritional characteristics, malted barley residue can be an important ingredient in the production of breads, cakes and cookies, among other preparations. These would be low-cost foods, representing savings both for the beer sector, which needs to dispose off the residue, and for the food industry, which currently uses more expensive ingredients, such as wheat flour.

\section{Conclusion}

The use of malted barley residue in the food industry can be an alternative to add value to this residue and another option to improve the nutritional quality of food, as an ingredient that is a source of fibre, minerals and proteins. The search for alternative uses of malted barley residue is important for the beer industry that can benefit not only from the valorization of this by-product, but also from the environmental perspective. The recycling and reuse of industrial residues and by-products becomes increasingly essential, and this being a sustainable way to take advantage of this residue, often discarded in nature incorrectly.

Thus, this research can contribute to the food industry, as it shows that malt bagasse has the potential to be used as a functional ingredient in the formulation of different products. Future researches can be carried out to develop these products. In addition, to assess whether the results would change, research on other malted barley residue would be interesting, publishing from the production of other types of beer or even obtained from a different country. The present research also contributes to preserving the environment, since the use of the malted barley residue by the food industry, avoiding its incorrect disposal in the environment, is a sustainable practice and ecologically correct that the beer industries can adopt, reducing the harmful impacts that waste could have on the environment.

\section{Acknowledgments}

The authors would like to acknowledge the support of the University Cesumar and to ICETI - Cesumar Institute of Science, Technology and Innovation. 


\section{References}

Albanese, L., Ciriminna, R., Meneguzzo, F., \& Pagliaro, M. (2017). Gluten reduction in beer by hydrodynamic cavitation assisted brewing of barley malts. LWT - Food Science and Technology, 82, 342-353. https://doi.org/10.1016/j.lwt.2017.04.060

Aliyu, S., \& Bala, M. (2011). Brewer's spent grain: A review of its potentials and applications. African Journal of Biotechnology, 10, 324-331. https://doi.org/10.5897/AJB11.2761

Amasuomo, E., \& Baird, J. (2016). The concept of waste and waste Management. Journal of Management \& Sustainability, 6, 88-96. https://doi.org/10.5539/jms.v6n4p88

Araújo, W. F., de Moura Rocha, L., de Souza Araújo, I. M., de Paula, G. A., de Sousa, L. S., Folha, M. F., ... Araújo, R. V. (2018). Sustainability in agroindustrys: Alternatives to avoid waste of agro-industrial residue peduncle cashew-a literature review. Brazilian Journal of Development, 4, 4546-4569.

Borges, M. S., \& de Assis, R. L. (2010). Uma análise de práticas de gestão sustentável do setor cervejeiro e a atividade pecuarista no estado do Rio de Janeiro. Revista de Gestão Social e Ambiental, 4, 35-51. https://doi.org/10.24857/rgsa.v4i1.212

Brasil. Ministério da Saúde. Agência Nacional de Vigilância Sanitária. Resolução-RDC no 360 , de 23 de dezembro de. (2003). Aprova Regulamento Técnico sobre Rotulagem Nutricional de Alimentos Embalados, tornando obrigatória a rotulagem nutricional. Diário Oficial da União, Brasília, DF, 26 dez. 2003. Retrieved

from http://portal.anvisa.gov.br/documents/10181/2718376/RDC_360_2003_COMP.pdf/caab87a1-e912-459f-8b c0-831a48b95da9.

Brasil. Ministério da Saúde. Agência Nacional de Vigilância Sanitária. Resolução-RDC $n^{\circ} 263$, de 22 de setembro de. (2005). Regulamento técnico para produtos de cereais, amidos, farinhas e farelos. Diário Oficial da União, Brasília, DF, 23 set. 2005. Retrieved from http://portal.anvisa.gov.br/documents/10181/2718376/RDC_263_2005_.pdf/2b494d48-0d39-4c8d-84d1-e2 0ec6e9190f.

Brasil. Ministério da Saúde. Agência Nacional de Vigilância Sanitária. Resolução RDC n ${ }^{\circ}$ 54, 12 de novembro de. (2012). Dispõe sobre o Regulamento Técnico sobre Informação Nutricional Complementar. Diário Oficial da União, Brasília, DF, 12 nov. 2012. Retrieved from http://portal.anvisa.gov.br/documents/10181/4825974/\%281\%29RDC_54_2012_.pdf/921d3c25-cef9-40d89b3f-7861eb7b8235. Acessed 18 April 2020

Budaraju, S., Mallikarjunan, K., Annor, G., Schoenfuss, T., \& Raun, R. (2018). Effect of pre-treatments on the antioxidant potential of phenolic extracts from barley malt rootlets. Food Chemistry, 266, 31-37. https://doi.org/10.1016/j.foodchem.2018.05.110

Colella, G., \& Jambrenghi, M. T. P. C (2020). Sustainable Supply Chain in the Agri-Food Sector in South-Italy as an Eco-Sustainability Tool for Innovation and Territorial Development. Journal of Management \& Sustainability, 10, 83-96. https://doi.org/10.5539/jms.v10n2p83

Cordeiro, L. G., El-Aouar, A. A., \& Gusmão, R. P. (2012). Caracterização do bagaço de malte oriundo de cervejarias. Revista Verde de Agroecologia e Desenvolvimento Sustentável, 7, 20-22.

Costa, G. M., Silva, V. R. O., Louzada, M. H., \& Queiroz, I. C. (2020). Elaboração e caracterização físico-química de farinha de bagaço de malte. Alimentos: Ciência, Tecnologia e Meio Ambiente, 1, 11-25.

do Nascimento Filho, W. B., \& Franco, C. R. (2015). Avaliação do potencial dos resíduos produzidos através do processamento agroindustrial no Brasil. Revista Virtual de Química, 7, $1968-1987$. https://doi.org/10.5935/1984-6835.20150116

Gaete, A. V., de Souza Teodoro, C. E., \& Martinazzo, A. P. (2020). Use of agro-industrial waste for cellulase production: A review. Research, Society and Development, 9, 1-33. https://doi.org/10.33448/rsd-v9i8.5785

Guo, M., Du, J., Zhang, Z., Zhang, K., \& Jin, Y. (2014). Optimization of Brewer's Spent Grain-Enriched Biscuits Processing Formula. Journal of Food Process Engineering, 37, 122-130. https://doi.org/10.1111/jfpe.12067

Instituto Adolfo Lutz. (2008). Métodos físico-químicos para análise de alimentos. São Paulo: Instituto Adolfo Lutz.

Jacometti, G. A., Mello, L. R. P. F., Nascimento, P. H. A., Sueiro, A. C., Yamashita, F., \& Mali, S. (2015). The physicochemical properties of fibrous residues from the agro industry. LWT - Food Science and Technology, 
62, 138-143. https://doi.org/10.1016/j.lwt.2015.01.044

Ktenioudaki, A., Chaurin, V., Reis, S., \& Gallagher, E. (2012). Brewer's spent grain as a functional ingredient for breadsticks. International Journal of Food Science \& Technology, 47, 1765-1771. https://doi.org/10.1111/j.1365-2621.2012.03032.x

Liszbinski, B. B., de Mello, E. S., Brizolla, M. M. B., Brum, A. L., Patias, T. Z., \& Baggio, D. K. (2020). Sustainability in Soybean Production from the Perspective of the Producers. Journal of Management \& Sustainability, 10, 138-151. https://doi.org/10.5539/jms.v10n1p138

Lousada Junior, J. E., Neiva, J. N. M., Rodriguez, N. M., Pimentel, J. C. M., \& Lôbo, R. N. B. (2005). Consumo e digestibilidade de subprodutos do processamento de frutas em ovinos. Revista Brasileira de Zootecnia, 34, 659-669. https://doi.org/10.1590/S1516-35982005000200036

Makowska, A., Mildner-Szkudlarz, S., \& Obuchowski, W. (2013). Effect of brewer's spent grain addition on properties of corn extrudates with an increased dietary fibre content. Polish Journal of Food and Nutrition Sciences, 63, 19-24. https://doi.org/10.2478/v10222-012-0061-9

Melo, A. A., Manfio, M., \& Rosa, C. S. (2016). Composição e propriedades tecnológicas da farinha do resíduo da fermentação da cerveja. Revista Brasileira de Produtos Agroindustriais, 18, 91-95. https://doi.org/10.15871/1517-8595/rbpa.v18n1p91-95

Melo, P. S., Bergamaschi, K. B., Tiveron, A. P., Massarioli, A. P., Oldoni, T. L. C., Zanus, M. C., ... de Alencar, S. M. (2011). Composição fenólica e atividade antioxidante de resíduos agroindustriais. Ciência Rural, 41, 1088-1093. https://doi.org/10.1590/S0103-84782011000600027

Meneses, N. G. T., Martins, S., Teixeira, J. A., \& Mussatto, S. I. (2013). Influence of extraction solvents on the recovery of antioxidant phenolic compounds from brewer's spent grains. Separation and Purification Technology, 108, 152-158. https://doi.org/10.1016/j.seppur.2013.02.015

Mussatto, S. I. (2014). Brewer's spent grain: A valuable feedstock for industrial applications. Journal of the Science of Food and Agriculture, 94, 1264-1275. https://doi.org/10.1002/jsfa.6486

Mussatto, S. I., Dragone, G., \& Roberto, I. C. (2006). Brewer's spent grain: Generation, characteristics and potential applications. Journal of Cereal Science, 43, 1-14. https://doi.org/10.1016/j.jcs.2005.06.001

Nascimento, R. F. D., Gavron, A. B., Bowles, S., Chaves, E. S., \& Bortolozo, E. A. F. Q. (2017). Determination of the sodium and potassium levels in meals served in a university restaurant in the south of Brazil. Brazilian Journal of Food Technology, 20, 1-7. https://doi.org/10.1590/1981-6723.16716

Nocente, F., Taddei, F., Galassi, E., \& Gazza, L. (2019). Upcycling of brewers' spent grain by production of dry pasta with higher nutritional potential. LWT - Food Science and Technology, 114, 108421. https://doi.org/10.1016/j.lwt.2019.108421

Panzarini, N. H., Rabbers, A., Trindade, J. L. F., Matos, E. A. S. A., Canteri, M. H. G., \& Bittencourt, J. V. M. (2014). Elaboração de bolo de mel enriquecido com fibras do bagaço da indústria cervejeira. Revista Brasleira de Tecnologia Agroindustrial, 8, 1154-1164. https://doi.org/10.3895/S1981-36862014000100002

Ricardino, I. E. F., Souza, M. N. C., \& da Silva Neto, I. F. (2020). Vantagens e possibilidades do reaproveitamento de resíduos agroindustriais. Alimentos: Ciência, Tecnologia e Meio Ambiente, 1, 55-79.

Rigo, M., Bezerra, J. R. M. V., Rodrigues, D. D., \& Teixeira, A. M. (2017). Physical-chemical and sensory characterization of cookies added with brewer's spent grain flour as fibre supply. Ambiencia, 13, 47-57. https://doi.org/10.5935/ambiencia.2017.01.03

Rocha, D. A., Abreu, C. M. P., Sousa, R. V., \& Corrêa, A. D. (2012). Obtaining method and analysis of the centesimal composition of fruit-of-wolf (Solanum lycocarpum St. Fil) flour. Revista Brasileira de Fruticultura, 34, 248-254. https://doi.org/10.1590/S0100-29452012000100033

Santos Rolim, C. S., Oliveira, R. T., Rolim, L. N., Saraiva-Bonatto, E. C., Saraiva, M. G. G., Oliveira, R. P. M., ... Lamarão, C. V. (2020). Quantitative analysis of bioactive compounds of Endopleura uchi pulp and peel extracts. Brazilan Journal of Development, 6, 16368-16383. https://doi.org/10.34117/bjdv6n3-491

Saraiva, B. R., Vital, A. C. P., Anjo, F. A., Cesaro, E., \& Matumoto-Pintro, P. T. (2018). Valorization of agro-industrial waste: sources of nutrients and bioactive compounds for human consumption. Pubsaúde, 1 , 1-11. https://doi.org/10.31533/pubsaude1.a007

Silva, I. G., Andrade, A. P. C., Silva, L. M. R., \& Gomes, D. S. (2019). Elaboration and sensory analysis of 
cookies made from avocado lump flour. Brazilian Journal of Food Technology, 22, 1-10. https://doi.org/10.1590/1981-6723.20918

Stefanello, F. S., Fruet, A. P. B., Simeonil, C. P., Chaves, B. W., Oliveira, L. C., \& Nornberg, J. L. (2014). Brewers' spentgrain: bioactivity of phenolic compounds; applicability in animal nutrition and functional foods. Revista Eletrônica em Gestão Educacional and Tecnologia, 18, 1-10. https://doi.org/10.5902/2236117012979

Tabela Brasileira de Composição de Alimentos - TACO. (2011). Tabela Brasileira de Composição de Alimentos. Campinas, Brazil. Retrieved from https://www.cfn.org.br/wp-ontent/uploads/2017/03/taco_4_edicao_ampliada_e_revisada.pdf

Terra, J., Antunes, A. M., Bueno, M. I. M. S., \& Prado, M. A. (2010). Um método verde, rápido e simples para determinar o valor energético de farinhas e cereais matinais. Química Nova, 33, 1098-1103. https://doi.org/10.1590/S0100-40422010000500017

Trujillo, J. G., Teixeira, M. A. S., Lima, A. H., Montão, D. P., Ross, T. B., Correa, G. R., ... Bezerra Júnior, P. S. (2018). Ethanol poisoning in cattle fed with malted barley residue with brewer's yeast. Pesquisa Veterinária Brasileira, 38, 382-386. https://doi.org/10.1590/1678-5150-pvb-5308

Veronezi, C. M., \& Jorge, N. (2012). Aproveitamento de sementes de abóbora (Cucurbita sp) como fonte alimentar. Revista Brasileira de Produtos Agroindustriais, 14, 113-124. https://doi.org/10.15871/1517-8595/rbpa.v14n1p113-124

Waters, D. M., Jacob, F., Titze, J., \& Arendt. E. (2012). Fibre, protein and mineral fortification of wheat bread through milled and fermented brewer's spent grain enrichment. European Food Research and Technology, 235, 767-778. https://doi.org/10.1007/s00217-012-1805-9

Word Health Organization. (2006). Reducing salt intake populations: Report of a WHO forum and technical meeting. Paris, France. Retrieved from https://www.who.int/dietphysicalactivity/Salt_Report_VC_april07.pdf

\section{Copyrights}

Copyright for this article is retained by the author, with first publication rights granted to the journal.

This is an open-access article distributed under the terms and conditions of the Creative Commons Attribution license (http://creativecommons.org/licenses/by/4.0/). 